\title{
Challenges in the supply of perishable products to island communities
}

\author{
by \\ Eric Calderwood \\ and \\ Paul Freathy*
}

Institute for Retail Studies

Stirling Management School

University of Stirling

Stirling

Scotland

FK9 4LA

j.p.freathy@stir.ac.uk

eric.calderwood@stir.ac.uk

*Contact author 


\title{
Challenges in the supply of perishable products to island communities.
}

\begin{abstract}
This paper examines the specific retail challenges associated with supplying island communities around the United Kingdom. It examines the main difficulties in supplying short shelf life products to both remote as well as larger urban island conurbations. Using a qualitative research methodology, the paper interviews individuals who have either strategic or operational responsibility for island retailing and supply. The research identifies a variety of factors that disproportionately influence the efficiency and effectiveness of a retailer's operations. It also notes that island retailers operate under a significantly different cost base from that of a mainland operation. While national multiple retailers may choose to absorb this additional expense into their overall cost base, many local retailers have followed a conglomerate strategy and operate wholesale or multi service functions.
\end{abstract}

\section{Keywords}

Island Retailing

Supply Chain

Collaboration

Interdependence

Perishable Products 


\section{Challenges in the supply of perishable products to island communities.}

\section{Introduction}

While island based communities can differ markedly from each other, they are according to Royle (2001) also subject to a common range of constraints as a result of their insularity. Often these issues include scale diseconomies in all dimensions of economic activity, an overdependence upon external trade, high costs of transportation and other infrastructural limitations (Kazazu 1994). Moreover their economies are often based on a single or limited range of commercial activities (Bass and Dalal-Clayton 1995).

A dependence upon the importation of consumer goods and services is therefore a common theme linking many island communities. While some products may be locally sourced, there is often a reliance upon importation either directly from abroad or via a neighbouring community. For example, products sold on the smaller islands of the British Isles arrive by ship from the UK mainland.

In addition to Great Britain and Ireland, the British Isles comprises over 6,000 small islands the majority of which are uninhabited. Those islands that have a permanent resident population vary quite markedly in terms of their size and access to services. Large, island based, market towns such as Portree (Isle of Skye), Douglas (Isle of Man) and Newport (Isle of Wight) have an established retail sector often with intense competition between local and national multiple retailers. On other, more remote 
islands, communities may be serviced by a single, multi-functional retail outlet, community shop or social enterprise.

From an academic perspective, the challenges that accompany the retailing and the supply of such goods is a relatively under-researched area. With a few exceptions, studies that have examined the demands of operating on an island have either focused upon the consumer choice factors (Byrom et al 2001; 2003; Armstrong et al 1991) or have incorporated the results into broader studies of rural retailing (Calderwood and Davies 2006).

The aim of this paper is to examine the challenges that retailers face when attempting to meet the needs of an island community. In particular it focuses upon three areas. First the paper details the stages and process involved in supplying products to island retailers. It then examines the primary challenges involved in supplying an island business. Finally the paper outlines the different strategies retailers have undertaken in order to respond to these challenges. The paper focuses upon short shelf life goods (primarily fresh and chilled products but also non food items such as newspapers) as these products represent amongst the most significant supply chain challenges, due to their continuous demand and the limited time when they are 'fit for purpose'.

To achieve the above aim, the paper is divided as follows; first, a conceptual framework for understanding the issues of product delivery is provided. This is followed by a brief discussion on the practical issues of supplying an island economy. After the methodology is outlined, the paper identifies the specific demands and pressures of operating upon an island. Finally a series of conclusions are drawn. 


\section{Supply of short shelf life products: theoretical considerations}

The reconfiguration of the UK retail supply chain over the past three decades has been well documented. While many aspects of this change merit explanation, three factors are of particular relevance to this paper. First, the growth of large multiple retail operators and the strategy of direct sourcing for certain product categories has fundamentally altered the structure of many product supply chains. As retail multiples have pursued a strategy of direct sourcing there has been either a reduced reliance on, or a total omission of wholesalers, agents and importers (Duffy and Fearne 2004a; Fearne et al 2005; Fernie and Sparks 2009). The advantages of supply chain rationalisation are well documented and revolve around the greater utilisation of resources, purchasing efficiencies and opportunities for greater supplier interaction (Fernie and Sparks 2009; Ogden and Carter 2008; Zokei and Simons 2006).

In addition to this, many retailers have chosen to reduce the total number of producers they work with on each product category (Hingley 2005a), opting instead to develop a 'preferred supplier' arrangement. A rationalisation of the supplier base is seen as a pre-requisite for the creation of more enduring retailer - supplier partnerships (Trent and Monczka 1999). A primary rationale for the pursuit of this strategy is to reduce the costs of carrying out economic exchanges. Stanford et al (1999) note for example that typical transaction costs also include the costs of locating suppliers, negotiating prices, drawing up contracts as well as monitoring the actions of the other party. The aim therefore has been to create relationships that help reduce the costs of these activities. 
Ruben et al (2007) note that while preferred relationships can initially involve higher (fixed and variable) production and handling costs, eventually they can lead to improved lead times, more accurate forecasting, savings on governance costs (handling practices / transport), improved quality and fewer out of stocks (see also Duffy and Fearne 2004b; Fearne et al 2001; Handfield et al 2000; Hingley 2005b; Park 2001; Quayle 2000).

Ruben et al (2007) also view the development of a 'preferred supplier' strategy as a gradual process that involves three stages. First, chain optimisation involves reducing governance costs and the development of larger centralised systems. Secondly, 'integral chain care' requires suppliers to invest in methods of improving quality and standards. Finally, a process of joint product development and innovation leads to the creation of working partnerships to meet specific consumer demands. This latter point was also noted by Stanford et al (1999) who maintained that better vertical cooperation could extend beyond a dyadic relationship and lead to the emergence of producer market groups working across the entire supply chain.

Despite the benefits that can accrue from such relationships, a number of studies have noted that small and medium size enterprises (SMEs) are often less able to capitalise upon such opportunities (Vaaland and Heide 2007). This may be due to a variety of reasons including the ability to implement at a strategic level, technical and budgetary constraints, vendor reluctance and managerial priority (see also Wagner et al 2003). 
Clements et al (2008) maintain that collaborative relationships have been evidenced within the fresh food supply chain. The inherent characteristics of short shelf life products (high levels of perishability, fragility and high risk of damage), can create uncertainty in the quality and reliability of supply. As they note, the heterogeneous nature of the supply chain for fresh products adds an additional degree of complexity to supply chain operations. The rationalisation of the supply base, dealing directly with suppliers, the fostering of closer working relationships and the integration of systems has led to the development of integrated rather than purely transactional working relationships (Hobbs and Young 2000).

Moreover Clements et al (2008) maintain that the role of fresh products is fundamental not only to generating customer footfall, but also to creating an identifiable strategic position within the market place. This reinforces Fearne and Hughes (1999) earlier findings on the increasing strategic importance of the UK fresh produce industry. As customer expectations have increased and individuals have become more discerning, key product categories are fundamental for the maintenance of a sustainable competitive offer. From a retailer perspective, the level of supply chain complexity is of fundamental importance when handling short shelf life products. The existence of multiple linkages interacting with each other has a direct influence upon the functioning of supply chain relationships (Perez et al 2006).

The above review of the literature informs the research in a number of ways. In addition to identifying the processes by which retailers are supplied with short shelf life products, the research examines the complexity of the channel and how this influences the structure of retail operations. Secondly, after identifying the main 
challenges involved in supplying local communities the research identifies whether preferred relationships / collaborative partnerships assist in the process. Finally as Vaaland and Heide (2007) maintain, the research comments on whether size is an influencing factor in helping to resolve the challenges of supplying island communities.

\section{Supply of short shelf life products: practical considerations}

Previous studies have incorporated the challenges of maintaining an island economy within a broader discussion of rural development. Bodies such as the Rural Development Commission and the Carnegie Trust have, for a number of years drawn attention to the issues of developing and sustaining an economy in remote locations (RDC 1994; Carnegie 2007; 2008).

Such research has highlighted the difficulties involved in creating a retail presence and maintaining a viable supplier base in such locations. For example, Binet and Wilson (1997), note the difficulties of maintaining a consistent supply of fresh products both for the local market as well as for export. Citing the example of Jersey potatoes, they highlight how the limited availability of land and a short growing season limits the ability of producers to grow sufficient volume and achieve any resulting economies of scale. They also highlight how distance from the primary consumer markets can make transportation costs prohibitive and effectively undermine the viability of supply. Such findings are reinforced by Byrom and Medway (2001), who identify how determinants such as weather, ferry availability and distance to market increase the complexity of supply chain operations. 
Other studies have focused upon retailing in a rural setting (Paddison and Calderwood 2007), or a more general discussion of independent retailers (Findlay and Sparks 2008). Byrom et al's (2001; 2003), research focused specifically upon island retailing. Their examination of the Western Isles examined the strategic options open to retailers in order to remain competitive over the long term. Essentially they identified a series of supply and demand side issues that provided a unique set of challenges for island retailers.

On the demand side, the islands were faced with declining populations as individuals migrated to the mainland in search of work. This created a diminishing customer base that was supplemented by tourism in the summer. On the supply side their research identified a number of product related issues linked to the remoteness and rurality of the islands. For example, not only was it more expensive to deliver to the islands, it was noted that supply from hauliers could be limited by factors such as the weather and the failure to achieve minimum order quantities. Their research reinforced the work of Armstrong et al (1991) whose study highlighted the additional transport costs involved in supplying retailers on the Isle of Man. These included port handling costs, insurance and demurrage ${ }^{\mathrm{i}}$. They maintained such costs could add over $4 \%$ to total freight expenditure.

Byrom et al $(2001 ; 2003)$ maintained that the strategic outcome of these factors is to shape the growth and direction of rural businesses on the island. They developed a 'funnical model' that highlighted a series of Market Led and Product Led expansion strategies. These included product expansion, symbol group membership and diversification into non core areas (opening petrol stations, cafes and operating a 
mobile shop). Their research also noted the opportunity afforded by mail order to sell local products such as jewellery and garments to a world wide audience. Such findings reinforce Binet and Wilson's (1997) work who noted the practical constraints placed upon organisational growth through both location and scale.

\section{Methodology}

To understand the issues involved in the supply of perishable goods to island communities, three island groups located around the British Isles were chosen - the Isle of Man, the Outer Hebrides (Harris and Lewis) and the Channel Islands (Jersey and Guernsey). These islands were selected as they provided a broad geographic spread, a degree of remoteness from mainland Britain (all taking three hours or more travelling time by conventional ferry) and a relatively significant residential population (approximately 158,000 in the Channel Islands, 80,056 on the Isle of Man and 19,919 people on Lewis and Harris).

Due to their size, these islands accommodated a variety of organisational forms (convenience, supermarket and superstore) and fascias (including retailers who also had outlets on the UK mainland, those who ran small chains exclusively on the islands as well as a number of independent retail operators). In addition, the three locations provided the opportunity to examine whether differences existed between urban and rural island communities. No census covering the range and scale of retail and service businesses was available and as a result this required the construction of an interview schedule using commercially available store data (IGD) and a range of business directories. In addition, the list of interviewees was supplemented after discussions with local people. 
The empirical data were gathered via semi structured interviews with individuals who had either strategic or operational responsibility for the supply or retail of perishable goods to island communities. This included four store managers from the two largest grocery multiples, as well as the manager of a large, UK based variety store (with a strong retail food business). The owners / Chief Executives of three island based multiple chains were also interviewed (including the operator of a symbol group convenience chain) together with a number of independent retail operators. To understand the specific logistical challenges involved in supplying an island community, a distribution manager from a UK multiple was interviewed together with the operations managers of two local companies who provided third party logistical support to the retail sector (Table 1).

Table 1 about here

Altogether 21 persons were interviewed with over 29 hours of qualitative research material being recorded. All interviews were conducted face to face and recorded with one exception, (which was conducted by telephone). The data were subsequently transcribed and analysed with key themes being identified through the use of established content techniques (Hsieh and Shannon 2005).

Each respondent was questioned on the three primary themes of the research; first, the process by which short shelf life products arrive / are delivered to stores, secondly, the main challenges each business faced in successfully achieving this and finally the strategies employed to overcome any difficulties that were encountered. The total 
number of interviewees was deemed sufficient, as by the end of the research, recurrent themes and issues were identified. The majority of interviews were undertaken at the respondents place of work and were therefore supplemented with site visits, informal discussions with staff as well as in-house documentation.

\section{Research Findings}

\section{Outline of the Supply Chain Process}

The first objective was to detail how short shelf life goods arrived at island retail stores. Figure 1 details the stages involved in the movement of product from supplier to store. As may be expected, the research identified differences from the mainland delivery process.

Figure 1 about here

In particular the ferry crossing added both time and cost to the procedure with sailing times varying from 3 to 14 hours depending on location. In addition, a buffer was built in to travel times in order to ensure that lorries arrived at the port in time to meet the ferry. This meant that deliveries from the mainland regional distribution centre (RDC) to the more remote stores could take up to 36 hours.

While some inter-island differences were noted, Figure 1 identifies three primary methods of store delivery from the ferry port. The first involved the direct delivery to store (usually by a third party). A second method saw the third party operator bringing 
product back to their own distribution centre (DC) for onward transportation to stores or collection by retailers. In a third example, product was shipped from the ferry port to the retailers own local distribution centre prior to delivery in store (the reasons behind this will be discussed later in the paper). In addition to these three methods, the research also noted a small number of local suppliers delivering direct to store or LDC.

The process of supplying products from the mainland was influenced by a number of factors outside the retailer's control. For example, adverse weather conditions had the potential to disrupt schedules and delay sailings ${ }^{\mathrm{ii}}$. In the event of a sailing being cancelled, most retailers had some form of contingency plan. For example, in the Western Islands of Scotland it was sometimes possible to use an alternative port and transport the load across the island by road. If no sailings took place, retailers had the option of waiting for the next departure or bringing the product back to the RDC for redistribution to other stores.

Weather conditions therefore added a level of complexity to island retailing (not least as once the ferries resumed many trucks and trailers were in the wrong location). However, the research also reinforced Byrom et al's (2001) findings that weather conditions were not the significant source of concern for retailers. While delays were a source of irritation, instances where a protracted period of bad weather could affect supply occurred infrequently (no more than $2-3$ times a year). A more regular occurrence that had to be factored in to the process was ferry 'down time' for maintenance. Perhaps surprisingly the research identified ferry operators who cancelled sailings rather than provide a replacement ferry while the regular boat was 
being maintained. This was often undertaken on a Sunday to minimise passenger disruption, however a number of interviewees noted that retailing operates seven days a week on many of the islands and such down times represented an unwelcome interruption. As one haulage contractor went on to state:

"The freight ferry is not very good in poor weather. Not ideal, an old, not very capable vessel and very unreliable. It can be difficult to get a booking on the boats following delays caused by weather.

The process of supplying products to an island could also be influenced by a companies own internal procedures. For example, one national multiple retailer centrally controlled its buying and ordering. Purchasing was handled by head office with suppliers delivering to a number of RDCs on the mainland. Given the size of the company and the diverse portfolio of outlets it operated, the island branch was treated the same as any other store by head office. The majority of supplier slots for delivery into the RDC were between 2100 and 2300 each night. This reflected the national supplier agreements contracted centrally by the company. However to make the journey to the port and be in time for the ferry crossing at 0215 , the lorry had to leave the depot by 2200 each night. This meant that supplier products that had not been delivered by 2200 were omitted from the load. As a consequence they were placed on the next available crossing twelve hours later. The outcome of this was limited availability and stock outs of certain products. Moreover the shelf life of many fresh and chilled products were reduced by an additional half a day, further increasing the likelihood of wastage (see also Byrom and Medway 2004).

This situation could be further compounded by the mechanical failure / breakdown of the transport fleet. In one example, a lorry had experienced a puncture before 
reaching the port. As a result it had missed the sailing and store replenishment of chilled and fresh goods was delayed by twelve hours.

While the above factors represented a challenge for operating a retail business on an island, the majority of interviewees had learnt to cope with these difficulties and plan accordingly. As one manager of a retail multiple noted:

"If you have the mindset that you are operating on an island you will compromise the way in which you manage the store.... We attempt to manage the store as if we were on the mainland. Our stock holding is calculated up until 1000 [when deliveries off the boat arrive in store] rather than 0600, apart from this we attempt to trade as any other store"

\section{The Primary Challenge}

The previous section underlined the complexity of maintaining a supply chain that seeks to meet the needs of an island community. Many of the factors that can influence the ability to service customers lie beyond the immediate control of the retailer. As the research demonstrated however, many respondents learnt how to cope with these day to day demands. The second stage of the research examined what respondents considered the most significant challenges in supply short shelf life products.

What represented the primary concern for the overwhelming majority of interviewees was the control of operational costs. This view dominated the research and it was noted that unless every cost involved in transporting goods and running stores was questioned, the sale of short shelf life (amongst many other categories) could easily become unprofitable. 
It was noted that almost every aspect of running a business on an island was more expensive than the mainland. For example, fuel prices were between 10 pence - 15 pence more expensive than the mainland, skilled retail staff could cost $40 \%$ more, while building costs (plumbers, electricians etc) were 40\% - 50\% more expensive. Also, given that staff rosters were often scheduled to coincide with store deliveries, any delays to the ferry system also added additional labour costs.

However the single largest additional cost of supplying an island population was the extra transportation charges that retailers incurred. For example, the fees for transporting product by ferry from the mainland were based upon a rate per metre. Table 2 highlights the published freight rates for a single journey between the Isle of Man and the UK (approximately 3hours 30 minutes).

Table 2 about here

In addition to the charges shown in the table, the shipping company also levied a fuel charge on each vehicle (currently $£ 8$ per metre) and a sliding scale of surcharges for vehicles over a certain width. For this reason, the majority of hauliers only loaded their trailers onto the ferries and used a separate tractor unit for unloading at the other end. To date, ferry companies had not begun to charge on the basis of vehicle height. As a consequence, a number of retailers used 'double decker' lorries ${ }^{\mathrm{iii}}$ in order to reduce the unit cost of transportation. 
Although effective in reducing the total number of loads required, using double deckers had a number of cost related effects. First, in order to gain from a bulk delivery, a number of smaller retail businesses held higher levels of inventory than immediately required, thereby affecting the company's cash flow ${ }^{\text {iv }}$. Secondly, while double decker lorries did have a number of advantages, they were significantly more expensive to manufacture $(£ 90 \mathrm{~K}$ - $£ 100 \mathrm{~K}$ as opposed to $£ 40 \mathrm{~K}$ - $£ 50 \mathrm{~K}$ for a conventional trailer). Moreover to allow access onto certain ferries, the headroom clearance for the trailer had to be reduced by a further six inches, a modification that further added to the cost of supplying the islands.

A further consequence of using the double decker system was that it required a small number of retailers to open local distribution centres (LDCs) (and bear the additional labour, rental and associated running costs). It was noted that large, composite lorries were unsuited to deliver to many smaller islands stores. As a consequence, some retailers were forced to use LDCs to break bulk and use smaller vans for individual store deliveries. This in turn led to a double handling of the product, additional costs and a further slowing down of deliveries.

Not only did this strategy delay the delivery of product and increase the amount of handling, it had the potential to impact upon the quality of the service. For example, one store had complained to the head office that the third party distributor they used was often late with orders that were also inaccurate. Given the remoteness of the location, the distributor had not been subject to the same standards of monitoring undertaken elsewhere in the organisation. This had led the parent company to 
develop additional (and costly) due diligence procedures in order to ensure that quality controls were maintained across its portfolio of island stores.

The opportunity to reduce transportation unit costs was often constrained by the limited opportunities to back haul product. This was partly due to the small base of island producers and the lack of local production. One island haulier interviewed noted that the closure of local fish farms over the past four years had led to a consequent decline in road freight and a $£ 2$ million drop in turnover for the business. The company currently delivered eight trailers per day for one national retailer, the majority of which now return empty to the mainland. As the respondent noted:

"There is an imbalance of freight as not very much is being manufactured or produced on the island. There used to be a large freight volume of fresh fish, however, three salmon fisheries have all pulled out ...... This results in empty vehicles travelling back to the mainland."

In addition, retailers paid a premium to transport their recycled materials. On the majority of islands there were limited or no industrial recycling facilities. Those that did exist were considered to be prohibitively expensive for large scale disposals. For example, one wholesale newspaper distributor noted that between $15 \%$ and $20 \%$ of its daily papers remained unsold. This combined with its weekly and monthly magazine returns, meant that the company had between $18-20$ tonnes of waste paper to dispose of per week. While some national multiple retailers were able to backhaul their cardboard waste to their mainland RDC on their own transport, island based retailers were required to use third party providers and pay extra for this additional service. 
The research has so far identified that the retailing of short shelf life products to island communities provides an added degree of complexity to the 'conventional' supply chain process. Moreover the research also noted that this complexity has the ability to impact upon both the cost structure and service levels provided across the sector. Nevertheless, many retailers have stores that continue to service the needs of island communities. The final objective of this research is to examine the strategies that have been employed that allow businesses to compete successfully in the market place.

Perhaps unsurprisingly the research findings confirmed a link between the strategies employed and the size of the organisation. The market power of larger retailers was seen to provide a distinct competitive advantage that helped mediate against some of the additional supply chain costs. At the risk of oversimplifying the analysis, differing approaches could be identified between local (small) retailers and the national (large) multiples.

For example, amongst a number of national multiple retailers, logistics was a centrally planned function. The additional expense of operating on an island was absorbed into the organisation's overall transport budget and not singled out as a separate business expense. While the pricing structure in store was often in the highest UK band ${ }^{\mathrm{v}}$, the decision had been made to mirror mainland prices. This obviously had an impact upon store margin but was a strategic decision made by the UK head office. 
Such an option was simply not available to smaller (primarily indigenous) retailers who had no facility (or flexibility) to absorb costs in a similar way. Many local retailers therefore found it difficult to compete on price. (One independent retailer noted that the large multiples were selling some products at the same price that they could buy it wholesale). This situation was most acute in towns or in larger communities where consumers could undertake direct price comparisons. Price parity was less of an issue in outlying areas as there was little competitive threat from national retailers. While this obviously did not prevent individuals from travelling to the towns, independents often stocked a broad assortment of goods and services as a way of generating footfall and reducing the need to travel. The research identified that many local retailers held an eclectic mix of products, including groceries, hardware, crafts, petrol and gas. In addition, some offered car and tractor parts as well as services such as a Post Office, bicycle hire, laundry rooms, public meeting areas and coffee shops.

Another strategy pursued by some smaller retailers was to emphasise the local nature of their products and services. This was seen as a way of reducing transport costs, differentiating the offer and "something you had to do" (supporting local suppliers). In the Channel Islands for example, one retailer offered a range of bakery products that were produced by its competitor, as this was seen as supporting local business. It was acknowledged however that 'going local' had met with only limited success. This was due to a number of reasons. First, national multiples often sourced similar local products, (many of the main multiple retailers have local / regional sourcing teams). While the research did identify a small number of local producers who did 
not wish to supply large volume retailers, these were in the minority. Secondly, a number of the islands visited had an eclectic population mix which included a high percentage of non-locals. For example, in the Channel Islands a large proportion of the working population were from other EU countries such as Poland, Portugal and the Baltic states. These individuals mainly occupied manual roles and their employment was designed to alleviate the tight labour market that existed. Similarly, the Isle of Man had a significant non indigenous population working in the financial services sector. As a consequence, demand for 'local' products was sometimes quite limited and retailers were obliged to stock a range of more popular national brands.

The research also identified that locally sourced products could be more expensive to stock compared to nationally available items. Some milk and meat produce were identified as being cheaper to source from the mainland. The presence of a price premium for local products can in turn create a dilemma for retailers. This was illustrated by one island based multiple retailer who asserted that "local sourcing is paramount to this island" shortly before going on to justify a buying decision that worked against a local product by stating that “... beef is cheaper in the market in Liverpool (on the mainland)."

The research also explored whether local suppliers were used as a means of offsetting the costs of transporting products from the mainland. What was revealed were significant gaps in local output which often reflected the absence of a sustainable agricultural base. While it remained possible to stock some local products, often producers could not provide either the volume or the consistency to supply the retail sector all year round. As one local shop owner went on to declare: 
"I buy some local products, such as fresh hen and duck eggs, however, I am finding that local suppliers are reluctant to get too tied up with red tape. ....I had been buying from a local supplier of strawberries, raspberries, peas and potatoes but this source closed when the grower moved out of the area and no on took his place."

It was also noted that local suppliers often did not produce enough variety to make a viable alternative range. For example, one grocery retailer maintained that while a local supplier produced a number of different cheeses, customers had demanded additional varieties and that they had little alternative but to source these from the UK.

Because of their size, multiple retailers had already achieved a 'critical mass' in terms of product volumes. This in turn led to a variety of cost savings through direct store deliveries, reduced ferry rates as well as product volume discounts. The research noted that a small number of local retailers attempted to emulate this approach and gain a buying mass in key product categories. Achieving this for local island retailers was considered to be difficult, not least because of the volumes demanded and the limited opportunities to expand their store portfolio. Such constraints partly explained the strategic direction and growth of a number of local businesses. For example, one retailer had established a wholesale function and serviced the needs of other stores as well as their own. This comprised making a round trip of nearly 60 miles every morning to collect deliveries from the wholesaler. On the return journey they delivered milk, bread and papers to other independent stores.

It was also common to identify retailers who also supplied the catering, bed and breakfast and hotel trade. Although seasonal, it represented another way of increasing 
product volumes as well as being an important source of income for many stores. Typically the retailer would consolidate these trade orders and make a single trip once a week to the wholesaler. Commitment to this operation varied, although it was more apparent in outlying areas. As the manager of one rural shop manager maintained:

"Local chefs are using the community shop to source fresh produce. Goods are ordered specifically for them, when the delivery comes we set it aside in the chill area for the chefs to uplift."

One indigenous retailer had taken this wholesaling activity one stage further and ran a small e-commerce business that allowed trade clients to order directly from its website. As part of its attempt to create a critical mass, this retailer had also set up a food preparation operation and produced a range of ready made deli items that it supplied to a range of outlets across the island.

Whilst not initially forming part of the research remit, the interviews with retailers identified a growing level of awareness regarding the potential influence of the internet on their business. Whilst for some, this had provided new market opportunities in form of sales and distribution (see also Byrom and Medway 2004), for others it had, it had led to a feeling of increased the competitive pressure. As one independent retailer noted:

"The Tesco home delivery is bound to have an impact, you see the vans whipping around the village. I know some of our customers buy their bulk order from Tesco and then only shop with us for some fresh foods and other bits and pieces." 


\section{Conclusions}

The aim of this paper was to highlight the main retail challenges involved in servicing the needs of an island community. It sought to first identify the means by which short shelf life produce is delivered from mainland locations to island stores. It then considered the primary challenges involved in achieving this objective. Finally the research identified the different ways in which retailers have attempted to overcome the constraints that island retailing place upon their operations.

While the populations and economies of islands around the UK differ quite significantly, the research identified a number of common issues that retailers are required to face. As noted at the outset of this paper, even on the mainland, the supply of short shelf life products remains a complex process and has been subject to rationalisation through direct sourcing and the removal of intermediaries. Supplying to an island community would seem to provide an additional and unavoidable layer of complexity.

While considered problematic, factors such as the weather were not the main concerns of the respondents. The primary problem concerned the management of costs within the supply chain. As the research illustrated, the operational costs of servicing an island community remains significantly greater than on the mainland. Higher labour, transport, recycling and utility charges were all cited as factors that influenced the overall cost structure within the supply chain. 
The research also demonstrated that differential buying margins meant that local retailers could not simply reduce prices in order to match the UK multiples. Only in the more remote island areas was price a less sensitive issue. Although outside the remit of this paper, further research may identify distinctive spatial trading patterns with independent retailers being located in the more remote outlying island areas.

In order to remain competitive, local retailers were therefore tasked with identifying ways of reducing costs, improving margins as well as differentiating their product offer. These pressures had in turn led to a variety of different strategies being pursued. The specific constraints of operating on an island also helped explain how many local retailers had struggled to grow their store portfolio. The limited population of many island communities and a lack of suitable locations restricted the opportunity for organic growth. In turn, this constrained the opportunity to negotiate volume discounts and prevented retailers from achieving a 'critical buying mass' from mainland suppliers.

As a consequence a trend towards vertical (wholesale / manufacturing) rather than horizontal (store) growth was identified. Such findings reinforce the work of Jussila et al. (1992) in their research of rural retail shops in Finland. Local retailers had sought other ways of expanding their operations and the research identified respondents who had created a wholesale function, broadened their merchandise mix, developed relationships with local businesses and established an e-commerce function. All these strategies not only provided additional sources of revenue but also helped improve buying volumes within the supply chain. 
However there was little evidence to suggest that the adoption of a vertical (wholesale / manufacturing) strategy had been developed by local retailers as a means of expanding beyond their immediate market (for example onto the mainland or other islands). The findings indicated that the focus was primarily upon meeting the needs of consumers in the local community.

Given that within the UK an acknowledged strategy has been towards supply based partnerships (vertical co-ordination) and away from retail owned manufacture (vertical integration) (Ruben et al 2007), the above findings reflect Byrom et al's (2003) observation that development strategies within island communities are influenced strongly by the geographical confines of the marketplace.

The research also failed to identify examples of 'preferred supplier arrangements' amongst the retailers interviewed (Ruben et al 2007). Few opportunities to adopt this practice were noted amongst local producers and the retail sector. The limited scale of the local supply base meant that there was little chance for either party to significantly reduce transaction costs, achieve economies of scale or improve availability through the development of long term partnerships (Stanford et al 1999; Binet and Wilson 1997).

Although falling outside the scope of this research, the perceived as well as the actual influence of the internet on the strategic decisions and performance of island retailers needs to be researched more fully in the future. Whilst some respondents were seen to be reacting to the challenges and opportunities offered by the internet, the extent of this response appeared to vary quite significantly. 
In conclusion this study has examined the specific issues involved in supplying island communities with short shelf life products. The research identified a number of unique challenges relating to transportation, local production and the formation of partnerships. At the same time, many of the imperatives previously identified as governing supply chain relationships could also be identified (Stanford et al 1999). Not least the requirement to control cost within the supply chain was a centrally recurring theme amongst respondents. Competitive advantage is partly predicated on the ability to control a wide range of operational expenditures. Again mirroring existing research (see for example, Vaaland and Heide 2007) the ability to react to such a challenge is in part a function of both size and scale. Large multiple retailers were better able to develop partnerships, achieve volume discounts and absorb expenditure into their overall cost structure. While supplying island communities undoubtedly provides a series of unique challenges, this paper has also demonstrated that an understanding of supply chain operations cannot be divorced from the broader competitive principles of cost management and market power. 


\section{References}

Armstrong, H., Johnes, G. and McBean, A. (1991) Consumer Goods and Energy Prices on the Isle of Man, Management Research News 14, no.7: 31-35.

Bass, S and Dalal-Clayton, B., (1995), Small Island States and Sustainable Development: Strategic Issues and Experience, Environmental Planning Group, International Institute for Environment and Development, London.

Binet, T. and Wilson, N. (1997), Developing niche product supply chains in the UK grocery market: lessons from a niche player, Supply Chain Management: An International Journal 2, no.1: 7-10.

Byrom, J. and Medway, D., (2001) Issues of provision and 'remoteness' in rural food retailing. A case study of the southern Western Isles of Scotland, British Food Journal 103, no.6: 400-412.

Byrom, J. and Medway, D. (2004) Cyber Solutions to Remote problems? Online Trading in British Overseas Territories - A Review and Research Agenda International Review of Retail, Distribution and Consumer Research 14, no. 1: 71-82.

Byrom, J., Medway, D. and Warnaby, G. (2003) Strategic alternatives for small retail businesses in rural areas, Management Research News 26, no.7: 33-49.

Byrom, J., Medway, D. and Warnaby, G. (2001) Issues of provision and "remoteness" in rural food retailing: A case study of the Southern Western Isles of Scotland, British Food Journal 103, no.6: 400-413.

Calderwood, E. and Davies, K. (2006), The impact of community co-operatives on shopping behaviour in rural communities in Scotland, Review of International Cooperation 99, no.1: 53-62.

Carnegie UK (2008) Bearing Fruit- Good Practice in asset-based rural community development, Development Trusts Association, Carnegie Trust UK, Dunfermline

Carnegie UK (2007) A Charter for Rural Communities- The final report of the Carnegie Commission for Rural Community Development, Carnegie Trust UK, Dunfermline

Clements, M., Lazo R. and Martin, S. (2008) Relationship connectors in NZ fresh produce supply chains , British Food Journal 110, no.4/5: 346 -360.

Duffy, R., and Fearne, A. (2004a), Partnerships in the retail food chain, in Bourlakis, M., and Weightman, P. (Eds), Food Supply Chain Management, Blackwell, Oxford.

Duffy, R., and Fearne, A. (2004b), Buyer-supplier relationships: an investigation of moderating factors on the development of partnership characteristics and performance, International Food and Agribusiness Management Review 7, no.2: 1-25. 
Fearne, A., Duffy, R.and Hornibrook, S. (2005), Justice in UK supermarket buyerseller relationships; Supermarkets; United Kingdom; Suppliers International Journal of Retail \& Distribution Management 33, no.8: 570-582

Fearne, A. and Hughes, D. (1999), Success factors in the fresh produce supply chain: insights from the UK, Supply Chain Management 4 no. 3: 120-128.

Fearne, A., Hughes, D. and Duffy, R. (2001), Concepts of collaboration - supply chain management in a global food industry, in Eastham, J., Sharples, L., and Ball, S. (Eds),Food and Drink Supply Chain Management - Issues for the Hospitality and Retail Sectors, Butterworth-Heinemann, London, pp.55-89.

Fernie, J. and Sparks, L. (2009), Retail Logistics: changes and challenges in Fernie, J. and Sparks, L. (eds) Logistics and Retail Management: emerging issues and new challenges in the retail supply chain, Kogam page, London.

Findlay, A. and Sparks, L. (2008), Weaving new retail and consumer landscapes in the Scottish Borders, Journal of Rural Studies 24: 86-97.

Handfield, R.B., Krause, D.R., Scannell, T.V., Monczka, R.M. (2000), Avoid the pitfalls in supplier development, Sloan Management Review 41, no.2: 37-53.

Hingley, M. (2005a), Power imbalanced relationships: cases from UK fresh food supply, International Journal of Retail \& Distribution Management 33, no.8: 551560.

Hingley, M. (2005b), Power imbalance in UK agri-food supply channels: learning to live with the supermarkets?, Journal of Marketing Management 21, no.1: 63-88.

Hobbs, J.E., Young, L.M. (2000), Close vertical co-ordination in agri-food supply chains: a conceptual framework and some preliminary evidence, Supply Chain Management: an International Journal 5 no.3, pp.131-42.

Hsieh, H.-F., \& Shannon, S.E. (2005). Three approaches to qualitative content analysis. Qualitative Health Research 15, no.9: 1277-1288.

Jussile, H., Lotvonen, E. and Tykkylainen, M., (1992) Business Strategies of Rural Shops in a Peripheral Region. Journal of Rural Studies 8, no.2: 185-192.

Kazazu 1994, Sustainable Development of Small Island Economies, www.geic.or.jp/islands/docs/kakazu.htme accessed $5^{\text {th }}$ August 2010.

Ogden, J. and Carter, P. (2008) The supply base reduction process: an empirical investigation. The International Journal of Logistics Management 19, no.1: 5-28.

Paddison, A. and Calderwood, E. (2007), Rural retailing: a sector in decline? International Journal of Retail \& Distribution Management 35, no.2: 136-135. 
Park, J.L. (2001), Supermarket product selection uncovered: manufacturer promotions and the channel intermediary. International Food and Agribusiness Management Review 4, no.2: 119-31.

Pérez, A., Ángeles, M. and Rodríguez, J. (2006), Size and inter-organisational relationships in the Canary Islands' food industry: From confrontation to collaboration. British Food Journal 108, no.11: 931-950.

Quayle, M. (2000), Supplier development for UK small and medium-sized enterprises. Journal of Applied Management Studies 9: 117-38.

Royle, S.A., (2001), “A Geography of Islands: Small Island Insularity”, Routledge, London

Ruben R., Boselie, D. and Lu, H. (2007), Vegetables procurement by Asian supermarkets: a transaction cost approach. Supply Chain Management: An International Journal 12, no.1: 60-68.

Rural Development Commission (1994) Village Shops Mean Business, Rural Development Commission, Salisbury.

Stanford, K., Hobbs, J., Gilbert, M., Jones, S., Price, M., Klein, K. and Kerr, W. (1999), Lamb-buying preferences of Canadian abattoirs and producer marketing groups: implications for the Canadian supply chain. Supply Chain Management: An International Journal 4, no.2, pp.86-94.

Trent, R.J. and Monczka, R.M. (1999), Achieving world-class supplier quality. Total Quality Management 10, no.6: 927-38.

Vaaland, T. and Heide, M. (2007), Can the SME survive the supply chain challenges? Supply Chain Management: An International Journal 12, no1: 20-31.

Wagner, B.A., Fillis, I., Johansson, U. (2003), E-business and e-supply in small and medium sized businesses. Supply Chain Management: An International Journal 8 no.4: 343-54.

Zokei, A. and Simons, D. (2006), Value chain analysis in consumer focus improvement: A case study of the UK red meat industry. The International Journal of Logistics Management 17, no.2: 141-162. 
Table1 Summary of Respondents

\begin{tabular}{|l|l|}
\hline & Comments \\
\hline Former Chief Executive of Retail & $\begin{array}{l}\text { Operates 15 island food stores selling } \\
\text { both food and non food products. In } \\
\text { addition, company has standalone } \\
\text { Department stores and travel business. }\end{array}$ \\
\hline Chief Executive of Symbol Group & $\begin{array}{l}\text { Operates 12 island convenience stores } \\
\text { selling food items and newspapers. }\end{array}$ \\
\hline National Distribution Manager & $\begin{array}{l}\text { Scottish based distribution manager for } \\
\text { one of the UK's largest retailers. Has } \\
\text { specific responsibility for servicing the } \\
\text { needs of the company's portfolio of } \\
\text { island stores. }\end{array}$ \\
\hline $\begin{array}{l}\text { Owner of Island based third party } \\
\text { logistics provider }\end{array}$ & $\begin{array}{l}\text { Company has contract for major retail } \\
\text { multiple. Responsible for moving product } \\
\text { from UK based RDC to island stores. }\end{array}$ \\
\hline $\begin{array}{l}\text { Operations Manager of Island based third } \\
\text { party logistics provider }\end{array}$ & $\begin{array}{l}\text { Interviewee works for same company as } \\
\text { above. }\end{array}$ \\
\hline $\begin{array}{l}\text { Operations Manager Island based third } \\
\text { party logistics provider }\end{array}$ & $\begin{array}{l}\text { Separate company from above } \\
\text { interviewees. Has contract for major } \\
\text { retail multiple. Also responsible for } \\
\text { moving product from UK based RDC to } \\
\text { island store. }\end{array}$ \\
\hline $\begin{array}{l}\text { Store Managers from Retail Multiples } \\
\text { Headquartered on UK mainland }\end{array}$ & $\begin{array}{l}\text { Five store managers operating retail } \\
\text { outlets on Western Isles, Isle of Man and } \\
\text { Channel Islands. }\end{array}$ \\
\hline Co- Owner of Island based retail chain & $\begin{array}{l}\text { Company operates retail and wholesale } \\
\text { function and has separate food } \\
\text { preparation business. }\end{array}$ \\
\hline Same organisation as above. \\
\hline Independent operators & $\begin{array}{l}\text { Company responsible for distributing } \\
\text { national newspapers \& magazines across } \\
\text { island. }\end{array}$ \\
\hline $\begin{array}{l}\text { Seven operators who operate independent } \\
\text { stores }\end{array}$ \\
\hline Ownewspaper
\end{tabular}


Table 2 Published freight rates between Isle of Man and UK

\begin{tabular}{|l|l|}
\hline Rate & Cost \\
\hline Standard Rate & $£ 67.50$ \\
\hline Regular Customer Rate & \\
\hline Up to 5,000 metres & $£ 62.50$ \\
\hline $5001-15000$ metres & $£ 62.40$ \\
\hline $15001-25000$ metres & $£ 62.35$ \\
\hline $25,000+$ & $£ 61.75$ \\
\hline
\end{tabular}




\section{Figure 1: Stages in the delivery of short shelf life products}

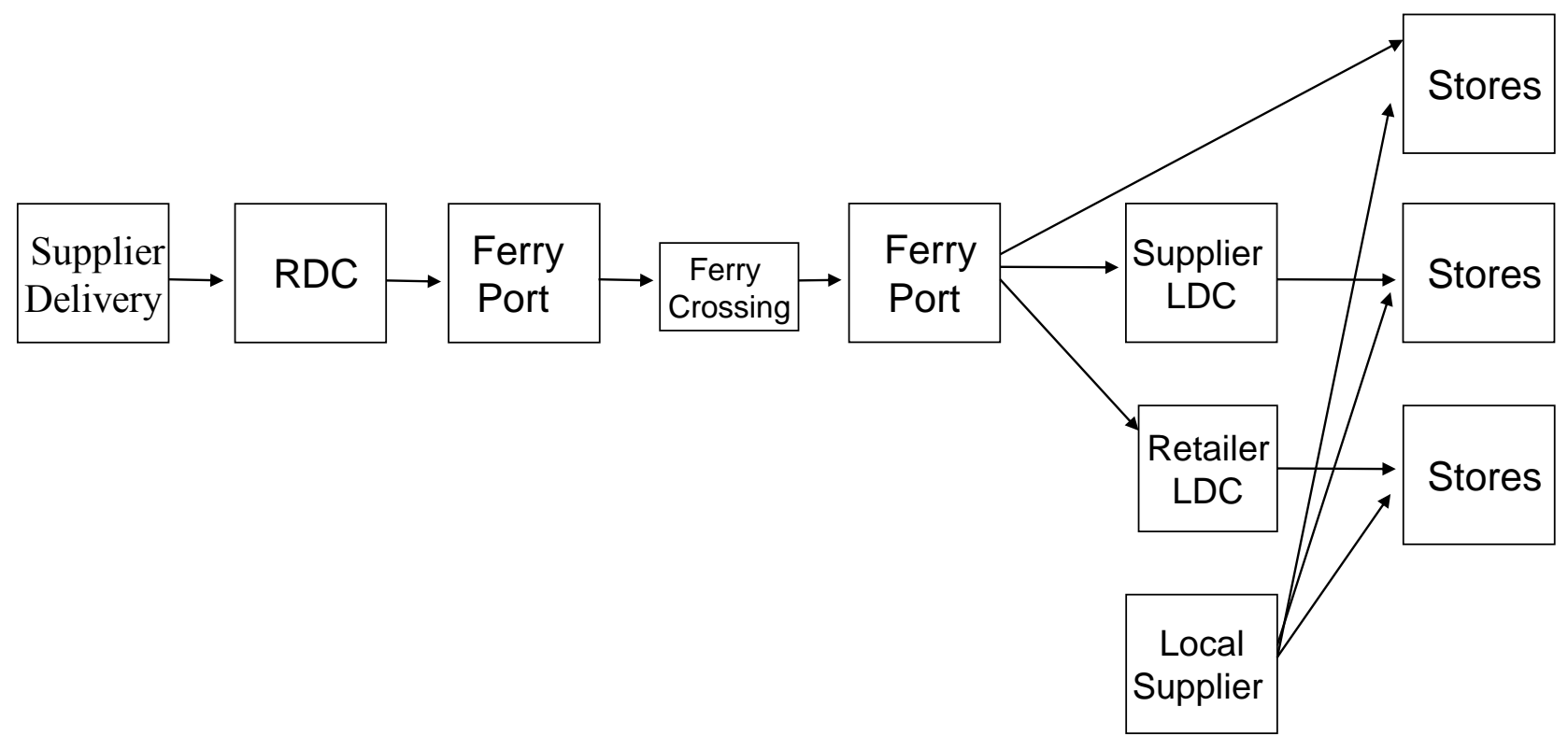


${ }^{\mathrm{i}}$ Demurrage refers to the period a vessel is in the possession of a charter company after the time normally given to charge and discharge the cargo (lay time). Demurrage is the amount a charterer will have to pay to the ship owner for its extra use of the vessel.

ii The research did note that a number of retailers had contingency plans in place should ferry disruption continue for more than a couple of days. Typically this involved the use of air transportation from the UK mainland (although this was considered an expensive option).

iii A number of ferry operators charge on the length rather than the height of the vehicle. Many distribution companies therefore operate twin deck composite transporters.

${ }^{\text {iv }}$ It should be noted that increased stock holding on an island is not necessarily a negative issue. Armstrong (1991) highlighted that because of the unpredictability of supply due to severe weather and technical difficulties, many retailers chose to hold higher levels of buffer stock than their mainland counterparts.

${ }^{\mathrm{v}}$ Some retailers apply a differential pricing policy depending upon the location of their stores and the format through which the product is sold. Typically individual stores are assigned to a 'band' which indicates the relative price bracket of the goods. 